\title{
Prone position and extracorporeal membrane oxygenation in acute respiratory distress syndrome
}

\author{
Posição prona e oxigenação por membrana extracorpórea \\ na síndrome do desconforto respiratório agudo
}

\section{Posición prona y oxigenación por membrana extracorpórea en el síndrome de dificultad respiratoria del adulto}

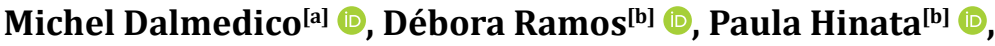 \\ Waleska Alves $^{[\mathrm{b}]}\left(\mathbb{D}\right.$, Chayane Carvalho $^{[\mathrm{a}]}$ (D), Juliana Avila ${ }^{[\mathrm{a}]}$ \\ [a] Pontifícia Universidade Católica do Paraná (PUCPR) Curitiba, PR, Brazil \\ [b] Universidade Positivo (UP), Curitiba, PR, Brazil
}

\section{Abstract}

Introduction: The acute respiratory distress syndrome is an inflammatory process originated by some pulmonary diseases, resulting in non-hydrostatic protein edema of the pulmonary parenchyma. The loss of the lung ability to eliminate carbon dioxide generates complications such as refractory hypoxemia, decreased alveolar dysplasia, increased complacency and hypercarbia. The treatment of acute respiratory distress syndrome, consist in measures to prevent lung diseases progression and optimize oxygenation. Objective: To identify, in the international scientific literature, cases or series of cases reporting the

\footnotetext{
* MD: Doctoral student, e-mail: micheldalmedico@yahoo.com.br DR: BS, e-mail: deramosbizetto@gmail.com PH: BS, e-mail: paahinata@gmail.com WA: undergraduate, e-mail: w.alvees@outlook.com CC: MS, e-mail: chaycarvalho7@gmail.com JA: Doctoral student, e-mail:juliana_londero@hotmail.com
} 
combined application of prone position and extracorporeal membrane oxygenation in patients with severe acute respiratory distress syndrome, as well as the benefit of these rescue therapies. Method: This is a systematic review of case reports that show the benefit of combined therapies in the treatment of patients with acute respiratory distress syndrome. Results: From the research strategy and selection criteria were included 8 studies reporting 19 cases of patients with acute respiratory distress syndrome who received the combination of the two rescue therapies. All studies showed that extracorporeal membrane oxygenation was the primary intervention. There were no reports of adverse events. Conclusion: The combinations of therapies positively interfere on the prognosis of patients with acute respiratory distress syndrome, in addition to presenting no additional risks in terms of the occurrence of adverse events; however, the prone position should precede the extracorporeal membrane oxygenation as first-line intervention.

PROSPERO Registration No. CRD42018093076

Keywords: Adult Respiratory Distress Syndrome. Extracorporeal Membrane Oxygenation. Prone Position. Case Reports. Evidence-Based Practice.

\section{Resumo}

Introdução: A síndrome do desconforto respiratório agudo trata-se de um processo inflamatório decorrente de uma variedade de doenças críticas, que resulta em edema proteico não hidrostático do parênquima pulmonar. o que determina hipoxemia refratária, lesão alveolar difusa, diminuição da complacência e hipercarbia secundária a perda da capacidade do pulmão para eliminar o dióxido de carbono. 0 tratamento da síndrome do desconforto respiratório agudo, consiste principalmente em medidas para evitar a progressão da lesão pulmonar e otimizar a oxigenação. Objetivo: identificar na literatura científica internacional casos ou séries de casos que reportem à aplicação combinada de posição prona e oxigenação por membrana extracorpórea em pacientes portadores de síndrome do desconforto respiratório agudo grave, bem como o benefício destas terapias de resgate. Método: trata-se de revisão sistemática de relatos de casos que traduzem o benefício das terapias combinadas no tratamento de pacientes com síndrome da angústia respiratória aguda. Resultados: a partir da estratégia de busca e critérios de seleção foram incluídos 8 estudos que relataram 19 casos de pacientes com síndrome do desconforto respiratório agudo que receberam a combinação das duas terapias de resgate. Todos os estudos evidenciaram que a oxigenação por membrana extracorpórea foi a intervenção primária. Não houve relato de eventos adversos. Conclusão: as combinações das terapias interferem positivamente no prognóstico dos pacientes portadores da síndrome do desconforto respiratório agudo, além de não apresentarem riscos adicionais em termos de ocorrência de eventos adversos, no entanto, a posição prona deve anteceder a oxigenação por membrana extracorpórea enquanto intervenção de primeira escolha. Registro PROSPERO CRD42018093076

Palavras-chave: Síndrome do Desconforto Respiratório do Adulto. Oxigenação por Membrana Extracorpórea. Decúbito Ventral. Relatos de Casos. Prática Clínica Baseada em Evidências.

\section{Resumen}

Introducción: El síndrome de dificultad respiratoria aguda es un proceso inflamatorio derivado de una variedad de enfermedades graves, que resulta en el edema proteico no hidrostático del parénquima pulmonar. Siendo que determina hipoxemia refractaria, displasia alveolar difusa, reducción de la complacencia e hipercarbia la pérdida de la capacidad del pulmón para eliminar dióxido de carbono. El tratamiento del síndrome de dificultad respiratoria aguda consiste principalmente en medidas para evitar la progresión de la lesión pulmonar y optimizar la oxigenación. Objetivo: identificar en la literatura científica internacional los casos o series de casos que revelan la aplicación combinada de la posición prona y la oxigenación con membrana extracorpórea en pacientes con síndrome de dificultad respiratoria aguda, así como el beneficio de estas terapias de rescate. Método: revisión sistemática de informes de casos que reflejan el beneficio de terapias combinadas en el tratamiento de pacientes con este síndrome. Resultados: desde la estrategia de búsqueda y los criterios de selección, se incluyeron 8 
estudios que informaron 19 casos de pacientes con este síndrome que recibieron una combinación de estos tratamientos de rescate. Todos los estudios evidenciaron que la oxigenación con membrana extracorpórea fue la intervención primaria. No hubo informes de eventos adversos. Conclusión: las combinaciones de terapias interfieren positivamente en el pronóstico de los pacientes con este síndrome, además de que no presentan riesgos adicionales a la ocurrencia de eventos adversos, sin embargo, la posición prona debe preceder a la oxigenación con membrana extracorpórea, mientras la intervención de primera elección. Registro PROSPERO CRD42018093076

Palabras clave: Síndrome de Dificultad Respiratoria del Adulto. Oxigenación por Membrana Extracorpórea. Posición Prona. Informes de Casos. Práctica Clínica Basada en la Evidencia.

\section{Introduction}

The acute respiratory distress syndrome (ARDS) is an inflammatory process that arises from a variety of critical diseases, resulting in a non-hydrostatic protein edema of the pulmonary parenchyma. This leads to refractory hypoxemia, diffuse alveolar damage, decreased complacency and hypercarbia secondary due to the loss of lung capacity to eliminate carbon dioxide [1].

A multicenter observational study (in 50 countries) with 29,144 patients indicated a prevalence of respiratory distress syndrome of $10.4 \%$ in all hospitalizations in intensive care units and $23.4 \%$ among all individuals in ventilatory support. The mortality rate reaches $46.1 \%$ for patients with severe acute respiratory distress syndrome [2].

Patients with acute respiratory distress syndrome are stratified into three categories: mild $(\mathrm{PaO} 2 /$ FiO $2 \leq 300 \mathrm{~mm} / \mathrm{Hg}$ with PEEP or CPAP $\geq 5 \mathrm{cmH} 2 \mathrm{O}$ ); moderate $(\mathrm{PaO} 2 / \mathrm{FiO} 2 \leq 200 \mathrm{~mm} / \mathrm{Hg}$ with $\mathrm{PEEP} \geq$ $5 \mathrm{~cm} / \mathrm{H} 2 \mathrm{O})$; and severe (PaO2 / FiO2 $\leq 100 \mathrm{~mm} / \mathrm{Hg}$ with PEEP > $5 \mathrm{~cm} / \mathrm{H} 2 \mathrm{O}$ ) [3].

The treatment of ARDS, especially in severely diseased patients, mainly consists of measures to avoid lung injury progression and to optimize oxygenation. In addition to the protective ventilatory strategy [4], are considered rescue therapies: alveolar recruitment maneuvers, prone position, inhaled nitric oxide, high-frequency oscillatory ventilation, and extracorporeal membrane oxygenation [5].

Such rescue therapies are temporary methods that can assist or replace the respiratory function in patients with severe acute respiratory failure refractory to conventional ventilatory support [5].

Among them, the prone position is recommended as first-line treatment for the acute respiratory distress syndrome, mainly in more severe patients [6]. The combined use of protective ventilatory strategy and prone position in periods between 16 and 20 hours in patients with ARDS with $\mathrm{PaO} 2 / \mathrm{FiO} 2$ ratio under 150 $\mathrm{mm} / \mathrm{Hg}$, with 48 hours of maximum disease evolution (exudative phase), results in increased oxygenation and significant reduction of the mortality rate [7].

Extracorporeal membrane oxygenation is an adjuvant therapy indicated when conventional ventilatory strategies do no result in improved arterial oxygenation and/or carbon dioxide elimination [8].

The prone position is part of the standard treatment in acute respiratory distress syndrome, whereas the venovenous extracorporeal membrane oxygenation is a rescue strategy that may ensure sufficient gas exchange in patients with respiratory acidosis and refractory hypoxemia to conventional measures [9]. The combination of extracorporeal membrane oxygenation and prone position corroborate the optimization of alveolar recruitment and reduce ventilator-induced lung injury, leading to fewer days of ventilatory support and stay in intensive care unit, improving the overall survival $[10,11]$.

Given the above, the objective of this study is to identify, in the international scientific literature, cases or series of cases reporting the combined application of prone position and extracorporeal membrane oxygenation in patients with severe ARDS, as well as the benefits of these rescue therapies.

\section{Method}

This is a systematic review, consisting of a design that synthesizes evidence based on the critical assessment and interpretation of relevant primary studies on a given issue, field of knowledge or phenomenon of interest. In this type of study, the scientific productions 
within a certain specialty are explored, identifying new ideas, methods and sub-themes that have received more or less emphasis in the chosen literature [12].

Randomized clinical trials are the type of study often included in these reviews. However, there is an increasing number of scientific research analyzing observational studies, such as cohort, case-control, cross-sectional studies and case series [13].

A systematic review from case reports or series contemplates situations in which it is impracticable to reproduce the clinical conditions (heterogeneity among individuals) for comparison between groups. In this context, the case report of a rare clinical event or a new intervention, when well detailed, becomes a source of evidence [12].

This study was protocoled in PROSPERO [14] (International Prospective Register of Systematic Reviews) under the registration number: CRD42018093076.

This study development emerges from the following research question: What is the effectiveness of the combination of prone position and extracorporeal membrane oxygenation in the treatment of patients with acute respiratory distress syndrome evidenced in case reports or series?

As this is a review of case reports, the use of the mnemonic PICO was not adopted for drafting the question since the aim was not to compare different adjuvant therapies in the ARDS treatment.

The electronic search of relevant theoretical framework occurred from January to July 2018, in the Scientific Eletronic Library Online (SciELO) and in the Latin American and Caribbean Center on Health Sciences Information (Lilacs) and Medical Literature Analysis and Retrieval System Online (MedLine) databases. Furthermore, the search for gray literature was conducted in extended abstracts of Congress annals (published or not), University repositories of theses and dissertations, and in references of manuscripts included.

The search strategy included the use of keywords and their synonyms in English: Medical Subject Headings (MeSH): Prone Position; Extracorporeal Membrane Oxygenation; Acute Respiratory Distress Syndrome. In addition to the methodological delimitation: Case Report OR Case Series. For databases in Portuguese, the Health Sciences Descriptors (DECS) were used: Decúbito Ventral, Oxigenação por Membrana Extracorpórea; Síndrome do Desconforto Respiratório Agudo. Terms were combined by Boolean operators " $A N D$ " or "OR".
Pubmed Strategy: "respiratory distress syndrome, adult"[MeSH Terms] OR "severe acute respiratory syndrome "[MeSH Terms] AND "prone position" [MeSH Terms] OR "prone positions "[MeSH Terms] AND "extracorporeal membrane oxygenation" [MeSH Terms] OR "extracorporeal circulation"[MeSH Terms].

As eligibility criteria, one considered the manuscripts available electronically, in Portuguese or English; reporting at least one case of ARDS with the combined use of the rescue therapies: prone position and venovenous extracorporeal membrane oxygenation, with any exposure time. Temporal limitations were not considered in the inclusion of studies. Studies that discussed the interventions separately, cases series in which one could not analyze the cases individually, or cases in which the patient died during the intervention were excluded.

The selection and analysis of potentially eligible studies and data extraction were conducted by two researchers, who assessed these articles independently. The inclusion process was composed of two phases: a) first screening - assessment of titles and abstracts of all studies identified; $b$ ) reading in full - evaluation of the full text.

The agreement among researchers was described with the Kappa measure [15], whose scoring variations indicate: 1 - complete agreement, and $-1-$ complete disagreement. Values equal to zero indicates that agreement is equivalent to that expected by chance. Disagreements during the study selection process were solved in consensus, by the intervention of a third reviewer.

All case reports included were analyzed by using the JBI Critical Appraisal Checklist for Case Reports from Joanna Briggs Institute Reviewer's Manual [16]. The critical assessment tool includes: patient demographic characteristics, patient history, clinical case clearly described and diagnostic confirmation, intervention description, outcome, adverse events, and implications for practice.

Results obtained were organized in a qualitative synthesis, including the general data: Author, year, title, journal and base showed on Table 1; and the clinical data: Length of stay in prone position with extracorporeal membrane oxygenation therapy, angulation of prone position, days of rescue therapies combination, daily hours of prone position, and the occurrence of adverse events showed onTable2.

The authors declare no conflicts of interest or any type of financing for the development of this study. 
Table 1 - Distribution of studies according to database, title, authors, years of publication, and journal. Curitiba, PR, Brazil, 2018

\begin{tabular}{|c|c|c|}
\hline Authors/Year & Title & Journal/Database \\
\hline He et al. (2017) [17] & $\begin{array}{l}\text { Successful rescue combination of extracorporeal membrane oxygenation, } \\
\text { high-frequency oscillatory ventilation and prone positioning for the } \\
\text { management of severe methicillin-resistant Staphylococcus aureus } \\
\text { pneumonia complicated by pneumothorax: a case report and literature } \\
\text { review }\end{array}$ & PubMed/ BMC Pulm Med \\
\hline Azimzadeh et al. (2017) [18] & $\begin{array}{l}\text { Prone position: Does it help with acute respiratory distress syndrome } \\
\text { (ARDS) requiring extracorporeal membrane oxygenation (ECMO)? }\end{array}$ & Gray Literature/ OJRD \\
\hline Brunauer et al. (2015) [19] & $\begin{array}{l}\text { Incomplete }\left(135^{\circ}\right) \text { prone position as an alternative to full prone position for } \\
\text { lung recruitment in ARDS during ECMO therapy }\end{array}$ & PubMed/ Winklin Wichenschr \\
\hline Masuda et al. (2014) [20] & $\begin{array}{l}\text { Effect of prone positioning on cannula function and impaired oxygenation } \\
\text { during extracorporeal circulation }\end{array}$ & PubMed/J Artific Organs \\
\hline Kredel et al. (2014) [21] & $\begin{array}{l}\text { Combination of positioning therapy and venovenous extracorporeal } \\
\text { membrane oxygenation in ARDS patients }\end{array}$ & PubMed/Perfusion \\
\hline Kipping et al. (2013) [22] & Prone position during ECMO is safe and improves oxygenation & PubMed/ Int J Artif Organs \\
\hline Litmathe et al. (2012) [23] & Prone and ECMO - a contradiction per se? & PubMed/ Perfusion \\
\hline Otterspoor et al. (2012) [24] & $\begin{array}{l}\text { Prolonged use of extracorporeal membrane oxygenation combined with } \\
\text { prone positioning in patients with acute respiratory distress syndrome and } \\
\text { invasive Aspergillosis }\end{array}$ & Pubmed/Perfusion \\
\hline
\end{tabular}

Source: The authors (2018).

Table 2 - Distribution of case studies, reporting length of stay in extracorporeal membrane oxygenation, combination of therapies in days and hours, angulation of the prone position, and adverse events. Curitiba, PR, Brazil, 2018

\begin{tabular}{|c|c|c|c|c|c|}
\hline Articles & $\begin{array}{l}\text { Length of } \\
\text { stay in ECMO }\end{array}$ & $\begin{array}{l}\text { Length of stay in ECMO } \\
\text { and prone (days) }\end{array}$ & $\begin{array}{l}\text { Length of stay in ECMO } \\
\text { and prone (hours/day; } \\
\text { total hours) }\end{array}$ & $\begin{array}{c}\text { Prone } \\
\text { Angulation }\end{array}$ & Adverse events \\
\hline He et al. (2017) [17] & 19 days & 12 days & 8 hours/day & $180^{\circ}$ & No adverse events \\
\hline Azimzadeh et al. (2017) [18] & 25 days & 8 days & 16 hours/day & $180^{\circ}$ & No adverse events \\
\hline Brunauer et al. (2015) [19] & 2 days & 2 days & 16 hours/day & $135^{\circ}$ & No adverse events \\
\hline Masuda et al. (2014) [20] & Unreported & 1 day & 15 hours/day & $180^{\circ}$ & Unreported \\
\hline $\begin{array}{l}\text { Masuda et al. (2014) [20] } \\
\text { Case } 2\end{array}$ & Unreported & 2 days & 15.5 hours/day & $180^{\circ}$ & Unreported \\
\hline Kredel et al. (2014) [21] & Unreported & $12 \mathrm{~h}$ average of each patient & $97 \mathrm{~h}$ in total & $135^{\circ}$ & No adverse events \\
\hline $\begin{array}{l}\text { Kredel et al. (2014) [21] } \\
\text { Case } 2\end{array}$ & Unreported & Unreported & $249 \mathrm{~h}$ in total & $135^{\circ}$ & No adverse events \\
\hline $\begin{array}{l}\text { Kredel et al. (2014) [21] } \\
\text { Case } 3\end{array}$ & Unreported & Unreported & $125 \mathrm{~h}$ in total & $135^{\circ}$ & No adverse events \\
\hline $\begin{array}{l}\text { Kredel et al. (2014) [21] } \\
\text { Case } 4\end{array}$ & Unreported & Unreported & $352 \mathrm{~h}$ in total & $180^{\circ}$ & No adverse events \\
\hline Kipping et al. (2013) [22] & 8 days & 6 days & Unreported & $180^{\circ}$ & Unreported \\
\hline $\begin{array}{l}\text { Kipping et al. (2013) [22] } \\
\text { Case } 2\end{array}$ & 10 days & 6 days & Unreported & $180^{\circ}$ & Unreported \\
\hline $\begin{array}{l}\text { Kipping et al. (2013) [22] } \\
\text { Case } 3\end{array}$ & 16 days & 13 days & Unreported & $180^{\circ}$ & Unreported \\
\hline $\begin{array}{l}\text { Kipping et al. (2013) [22] } \\
\text { Case } 4\end{array}$ & 14 days & 6 days & Unreported & $180^{\circ}$ & Unreported \\
\hline $\begin{array}{l}\text { Kipping et al. (2013) [22] } \\
\text { Case } 5\end{array}$ & 5 days & 5 days & Unreported & $180^{\circ}$ & Unreported \\
\hline $\begin{array}{l}\text { Kipping et al. (2013) [22] } \\
\text { Case } 6\end{array}$ & 6 days & 4 days & Unreported & $180^{\circ}$ & Unreported \\
\hline Litmathe et al. (2012) [23] & 9 days & 3 days & 4 hours/day & $135^{\circ}$ & No adverse events \\
\hline $\begin{array}{l}\text { Litmathe et al. (2012) [23] } \\
\text { Case } 2\end{array}$ & 4 days & 4 days & 4 hours/day & $135^{\circ}$ & No adverse events \\
\hline Otterspoor et al. (2012) [24] & 45 days & 3 days & Unreported & $180^{\circ}$ & No adverse events \\
\hline $\begin{array}{l}\text { Otterspoor et al. (2012) [24] } \\
\text { Case } 2\end{array}$ & 52 days & 6 days & Unreported & $180^{\circ}$ & No adverse events \\
\hline
\end{tabular}

Source: The authors (2018). 


\section{Results}

After the execution of the search strategy, 39 studies that initially fit the eligibility criteria were recovered (Figure 1). Later, after the assessors' examination, 12 studies were completely analyzed; 8 composed the final sample of this systematic review. The score of the concordance index (Kappa) regarding the exclusion or inclusion of studies was $0.073(\mathrm{p}=<0.001)$.

In total, 31 articles were excluded, 8 were duplicated in the databases, 10 did not combined rescue therapies of extracorporeal membrane oxygenation and prone position, 7 were literature reviews, 3 were randomized studies, 2 fitted the inclusion criteria but were not found in the complete version, and 1 did not quote the respiratory distress syndrome

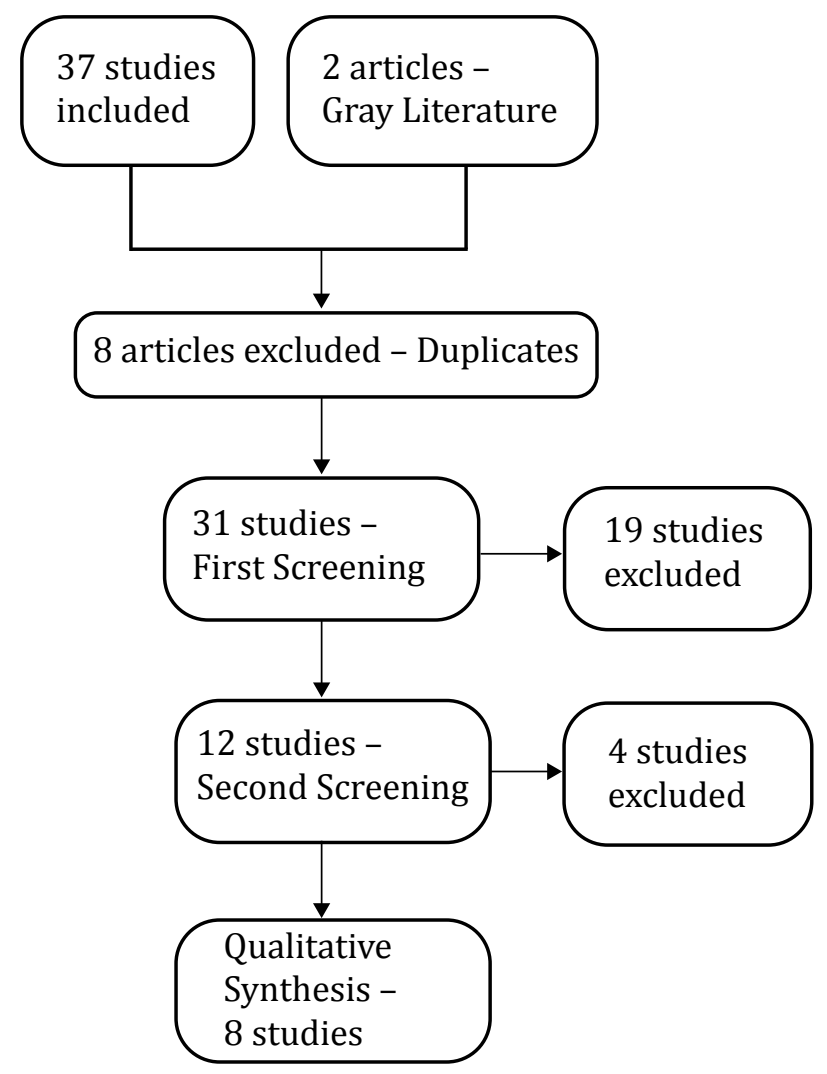

Figure 1 - Flowchart of identification, exclusion process, and selection of studies - Curitiba, PR, Brazil, 2018

Source: The authors (2018).

All case reports included adopted, as initial intervention, the use of extracorporeal membrane oxygenation for patients with acute respiratory distress syndrome. Whereas the prone position was additionally implemented due to refractory hypoxemia. There was no consensus regarding the daily permanence of patients in prone position, with variations between 4 and 16 hours, and it was not possible to extract this information from all reports. The angulation of patients in prone position ranged between $135^{\circ}$ and $180^{\circ}$. Data related to total time (days) of individual use of extracorporeal membrane oxygenation, and combination of prone position and extracorporeal membrane oxygenation was also not reported in all studies.

The case reports included were subjected to critical methodological analysis by the Critical Appraisal Checklist for Case Reports tool.

All studies have approached the sociodemographic and clinical characteristics of patients; however, one of these studies brings incomplete information [20]. Regarding health history, two reports did not mention any information [20,21].

Regarding the presentation of the patient's clinical case, most reports satisfactorily describe the health state. However, in a case reported in the studies [23, $24]$, there is no clarity on this information; whereas an article omitted the data inherent to the clinical conditions of subjects treated [20].

Concerning the diagnosis of the disease and its presentation, only one study did not provide sufficiently clear information [23], whereas one case did not make any mention to a diagnostic determination [20].

About the implementation of intervention procedures, two studies did not bring complete information on the operationalization of techniques $[19,21]$; and one report did not describe any information [20].

Regarding the description of a case clinical evolution after the introduction of therapy, four studies $[17,19-21]$ and one of the cases of a series [23] did not objectively report the results obtained.

Most studies cited that there were no adverse events during the use of combined therapies. Thus, we consider as reporting bias the fact that some studies $[20,22]$ provide no information on the occurrence of adverse events, thus preventing the determination of the presence or not of these complications.

All studies brought information and relevant contributions to embrace a combination of prone position and extracorporeal membrane oxygenation in clinical practice.

Although the studies do not contemplate all the items recommended by Joanna Briggs's tool, the 
instrument does not determine a cutoff point for the inclusion and exclusion of studies according to methodological quality.

\section{Discussion}

The aim of this systematic review was to assess the benefits of combining prone position and extracorporeal membrane oxygenation in the treatment of patients with ARDS. During the research, were identified 8 articles that reported 19 cases of concomitant use of prone position and extracorporeal membrane oxygenation in patients with acute respiratory distress syndrome with refractory hypoxemia.

Separately, the prone position contributes to the improvement of respiratory mechanisms and assists in the optimization of ventilatory distribution, alveolar recruitment and perfusion, thus ensuring improved oxygenation, which facilitates the increase of pulmonary volume, decreasing the occurrence of atelectasis, enabling better drainage of secretion and reduction of ventilator-induced lung injury, resulting in reduced oxygen demand, decreased airway pressure and, consequently, decreased time in ventilatory support and mortality rate $[25,26]$.

Therefore, extracorporeal membrane oxygenation has been used as a rescue therapy for the ARDS, promoting optimization of blood oxygenation, removal of $\mathrm{CO} 2$ (a potent biological agent that, in high levels becomes a hypercapnia, causing deleterious effects in the lung), decrease in the resorption rate of the alveolar fluid, inhibition of alveolar cells proliferation, and circulatory support, in addition to enable the protective and ultra-protective mechanical ventilation ( $<3-4 \mathrm{~mL} / \mathrm{kg}$ of current volume), creating opportunities for the recruitment of alveolar-capillary units from poorly aerated areas in dependent lung regions [27, 28].

Another relevant aspect is noticed in the decreased need of sedatives, which is reflected in days free of ventilatory support, less use of vasopressors and reduced length of stay in hospital and intensive care unit [29].

When combined, prone position and extracorporeal membrane oxygenation (venovenous configuration) for periods longer than 12 hours in patients with severe acute respiratory failure maximize alveolar recruitment, respiratory complacency, oxygenation (shown by the significant improvement of the $\mathrm{PaO} 2$ /
FiO2 ratio) and the recruitment of ventilator-induced lung injury, thus determining shorter hospitalization time and better overall survival [30-32].

A retrospective study with 17 patients showed that, when used in combination, venovenous extracorporeal membrane oxygenation and prolonged prone position (for 24 hours) improve the oxygenation - the $\mathrm{Pa} 02 / \mathrm{FiO} 2$ ratio significantly increased from $111( \pm 84-128)$ to $173( \pm 120-203)$ $\mathrm{mmHg}-\mathrm{p}<0.0001-$ and the respiratory system complacency - increased from $18( \pm 12-36)$ to 32 $( \pm 15-36) \mathrm{ml} / \mathrm{cmH} 20-\mathrm{p}<0.0001$. In addition, the study did not demonstrate the occurrence of serious adverse events. However, in this study, patients were primarily treated with extracorporeal membrane oxygenation, getting prone in cases of unsuccessful weaning of the extracorporeal life support, refractory hypoxemia or persistence of high values of plateau pressure [32].

Another similar research assessed the safety and feasibility of the extracorporeal membrane oxygenation and prone position combination. In total, 26 patients were treated with venovenous extracorporeal membrane oxygenation to recover from severe ARDS. Patients remained an average of 12 hours per day in the prone position. No significant adverse event was registered during the use of prone position [33].

All studies included in this review adopted as initial measure the extracorporeal membrane oxygenation, making the prone position a support condition - under-utilization. This data conflict the scientific evidence supporting the use of prone position as a first-line intervention.

It is noteworthy that, despite the reliable scientific evidence about a large randomized and controlled clinical trial (PROSEVA) [34], consolidated by various meta analyses [25, 35, 36] proving the benefits of prone position for the outcome mortality, this technique is rarely implemented before extracorporeal membrane oxygenation in treating the severe ARDS [37]. Thus, studies carried out after 2013 should ideally adopt the recommendations for the practice of prone position [34]. Analyzing studies conducted after this period, we observed that three cases did not use the minimum time of permanence recommended in prone position $[17,20]$.

The prospective multicenter international study APRONET (ARDS Prone Position Network) $-6,723$ patients of 141 intensive case 
units in 20 countries - investigated the use of prone position in patients with ARDS. Results obtained showed that prone position was generally underutilized, or used in patients with soft acute respiratory distress syndrome who, therefore, would not require prone position treatment [38].

In turn, the scientific evidence from multicenter international randomized clinical trials (EOLIA Trial and CESAR) that supports the use of extracorporeal membrane oxygenation in patients with ARDS for mortality outcome in 60 days is inconclusive $[39,40]$.

The low adherence to prone as initial therapy in treating the respiratory distress syndrome can be explained by the lack of knowledge on the practice, as well as by the lack of training of professionals or even their doubt concerning the positive results of this practice. Another aspect that may explain this behavior may be the fact that using the extracorporeal membrane oxygenation generates high profit to institutions, whereas the prone position is a lowcost procedure, sometimes not even reimbursed [37]. Based on current prices in Brazil, the equipment costs from $\$ 8,000$ to $\$ 36,000$ dollars per patient [41].

A multicenter cohort study assessed the clinical outcomes of 62 patients with severe ARDS, of which 28 were submitted to prone position prior to extracorporeal membrane oxygenation, while the others received exclusively extracorporeal membrane oxygenation. The prone group showed lower rates of extracorporeal membrane oxygenation at weaning and a higher weaning success percentage of ventilatory support, consequently, staying fewer days in ventilatory support and hospital. Mortality rate in 30 days was $21 \%$ in the prone group and $41 \%$ in the group that received no prone treatment $(\mathrm{p}=0.098)$ [42].

Despite the studies reporting extracorporeal membrane oxygenation as initial rescue therapy, the scientific evidence available suggests that for ensuring better treatment effectiveness by using the prone position as first intervention after the early diagnosis of ARDS [43].

In this context, the results of EOLIA study showed that early performance of extracorporeal membrane oxygenation in specialized reference centers is safe and can be a feasible alternative as a rescue therapy in patients with severe ARDS, after the absence of hemogasometric improvement using protocol interventions such as protective ventilatory support and prone position [39]. Therefore, extracorporeal membrane oxygenation should not be considered a first-line therapy for patients with severe respiratory failure, as the benefits of prone position are observed mainly in the exudative phase of the acute respiratory distress syndrome.

\section{Conclusion}

Prone position is considered to be simple, with low operating costs and proven to be beneficial. On the other hand, extracorporeal membrane oxygenation is a high-cost and high-complexity technology, technically challenging, and that still does not present scientific evidence that support its routine practice, demanding studies with greater methodological strength.

Thus, on the contrary of presented in this research results, the prone position shall be adopted as first-line rescue measure for patients with severe ARDS in preference to the use of extracorporeal life support.

Despite the gaps of knowledge for evidencebased practice, the use of extracorporeal membrane oxygenation enables the implementation of ultraprotective ventilation, a preponderant factor for the reduction of ventilator-induced injury, which is the main cause of patients' death with acute respiratory distress syndrome.

Although there are no clinical trials proving the effectiveness and safety of using extracorporeal membrane oxygenation in prone position, we have observed, by systematic review of case reports, that the combination of these therapies positively interfere in the prognosis of patients with ARDS, in addition to not presenting additional risks regarding the occurrence of adverse events.

Therefore we emphasize the need for controlled clinical trials to assess the long-term impact of combined rescue therapies for the mortality outcome, as well as the effects of permanence in ventilatory support, hospitalization time and occurrences of adverse events, with the purpose of establishing protocol conducts inherent to the treatment of acute respiratory distress syndrome.

\section{References}

1. Rezoagli E, Fumagalli R, Bellani G. Definition and epidemiology of acute respiratory distress syndrome. Ann Transl Med. 2017;5(14):282. 
2. Bellani G, Laffey JG, Pham T, Fan E, Brochard L, Esteban A, et al. Epidemiology, patterns of care, and mortality for patients with Acute Respiratory Distress Syndrome in Intensive Care Units in 50 countries. JAMA. 2016;315(8):788-800.

3. ARDS Definition Task Force, Ranieri VM, Rubenfeld GD, Thompson BT, Ferguson ND, Caldwell E, et al. Acute respiratory distress syndrome: the Berlin definition. JAMA. 2012;307(23):2526-33.

4. Acute Respiratory Distress Syndrome Network, Brower RG, Matthay MA, Morris A, Schoenfeld D, Thompson BT, et al. Ventilation with lower tidal volumes as compared with traditional tidal volumes for acute lung injury and the acute respiratory distress syndrome. N Engl J Med. 2000;342(18):1301-8.

5. Alessandri F, Pugliese F, Ranieri VM. The role of rescue therapies in the treatment of severe ARDS. Respir Care. 2018;63(1):92-101.

6. Moerer O, Tonetti T, Quintel M. Rescue therapies for acute respiratory distress syndrome: what to try first? Curr Opin Crit Care. 2017;23(1):52-9.

7. Dalmedico MM, Salas D, Oliveira AM, Baran FDP, Meardi JT, Santos MC. Efficacy of prone position in acute respiratory distress syndrome: overview of systematic reviews. Rev Esc Enferm USP. 2017;51:e03251.

8. Goligher EC, Ferguson ND, Brochard LJ. Clinical challenges in mechanical ventilation. Lancet. 2016;387(10030):1856-66.

9. Lucchini A, De Felippis C, Pelucchi G, Grasselli G, Patroniti N, Castagna L, et al. Application of prone position in hypoxaemic patients supported by venovenous ECMO. Intensive Crit Care Nurs. 2018;48:61-8.

10. Culbreth RE, Goodfellow LT. Complications of prone positioning during extracorporeal membrane oxygenation for respiratory failure: a systematic review. Respir Care. 2016;61(2):249-54.

11. Ferguson ND, Guérin C. Adjunct and rescue therapies for refractory hypoxemia: prone position, inhaled nitric oxide, high frequency oscillation, extra corporeal life support. Intensive Care Med. 2018;44(9):1528-31.
12. Higgins JPT, Green S, editors. Cochrane handbook for systematic reviews of interventions [Internet]. Version 5.1.0. London: The Cochrane Collaboration; 2011.

13. Centre for Reviews and Dissemination. Systematic reviews: CRD's guidance for undertaking reviews in health care. York: University of York, CRD; 2009.

14. Centre for Reviews and Dissemination. PROPERO: International Prospective Register of Systematic Reviews. York: University of York; 2013 Oct 27 [cited 2018 Jan 31]. Available from: http://bit.ly/2m0HoEC.

15. Hulley SB, Cumming SR, Browner WS, Grady DG, Hearst NB, Newman TB. Delineando a pesquisa clínica: uma abordagem epidemiológica. 3rd ed. Porto Alegre: Artmed; 2008.

16. The Joanna Briggs Institute. Joanna Briggs Institute Reviewers' Manual: 2016 edition: JBI Critical Appraisal Checklist for Case Reports. Australia: The Joanna Briggs Institute; 2016.

17. He H, Wang H, Li X, Tang X, Wang R, Sun B, et al. Successful rescue combination of extracorporeal membrane oxygenation, high-frequency oscillatory ventilation and prone positioning for the management of severe methicillin-resistant Staphylococcus aureus pneumonia complicated by pneumothorax: a case report and literature review. BMC Pulm Med. 2017;17(1):103.

18. Azimzadeh N, Baram M, Cavarocchi N, Hirose H. Prone position: does it help with acute respiratory distress syndrome (ARDS) requiring extracorporeal membrane oxygenation (ECMO)? OJRD. 2017;7(1):18-24.

19. Brunauer A, Dankl D, Dünser MW. Incomplete (135) prone position as an alternative to full prone position for lung recruitment in ARDS during ECMO therapy. Wien Klin Wochenschr. 2015;127(3-4):149-50.

20. Masuda Y, Tatsumi H, Imaizumi H, Gotoh K, Yoshida S, Chihara S, et al. Effect of prone positioning on cannula function and impaired oxygenation during extracorporeal circulation. J Artif Organs. 2014;17(1):106-9.

21. Kredel M, Bischof L, Wurmb TE, Roewer N, Muellenbach RM. Combination of positioning therapy and venovenous extracorporeal membrane oxygenation in ARDS patients. Perfusion. 2014;29(2):171-7. 
22. Kipping V, Weber-Carstens S, Lojewski C, Feldmann $P$, Rydlewski A, Boemke W, et al. Prone position during ECMO is safe and improves oxygenation. Int J Artif Organs. 2013;36(11):821-32.

23. Litmathe J, Sucker C, Easo J, Wigger L, Dapunt O. Prone and ECMO: a contradiction per se? Perfusion. 2012;27(1):78-82.

24. Otterspoor LC, Smit FH, van Laar TJ, Kesecioglu J, van Dijk D. Prolonged use of extracorporeal membrane oxygenation combined with prone positioning in patients with acute respiratory distress syndrome and invasive Aspergillosis. Perfusion. 2012;27(4):335-7.

25. Mora-Arteaga JA, Bernal-Ramírez OJ, Rodríguez SJ. The effects of prone position ventilation in patients with acute respiratory distress syndrome: a systematic review and metaanalysis. Med Intensiva. 2015;39(6):359-72.

26. Koulouras V, Papathanakos G, Papathanasiou A, Nakos G. Efficacy of prone position in acute respiratory distress syndrome patients: a pathophysiology-based review. World J Crit Care Med. 2016;5(2):121-36.

27. Peek GJ, Moore HM, Moore N, Sosnowski AW, Firmin RK. Extracorporeal membrane oxygenation for adult respiratory failure. Chest J. 1997;112(3):759-64.

28. Makdisi G, Wang IW. Extra corporeal membrane oxygenation (ECMO) review of a lifesaving technology. J Thorac Dis. 2015;7(7):e166-76.

29. Morales-Quinteros L, Artigas A. Extracorporeal membrane oxygenation in acute respiratory distress syndrome: does it really help? J Thorac Dis. 2018;10(Suppl 26):S3166-8.

30. Kimmoun A, Guerci P, Bridey C, Ducrocq N, Vanhuyse F, Levy B. Prone positioning use to hasten venovenous ECMO weaning in ARDS. Intensive Care Med. 2013;39(10):1877-9

31. Guervilly C, Hraiech S, Gariboldi V, Xeridat F, Dizier $\mathrm{S}$, Toesca R, et al. Prone positioning during venovenous extracorporeal membrane oxygenation for severe acute respiratory distress syndrome in adults. Minerva Anestesiol. 2014;80(3):307-13.
32. Kimmoun A, Roche S, Bridey C, Vanhuyse F, Fay R, Girerd N, et al. Prolonged prone positioning under VV-ECMO is safe and improves oxygenation and respiratory compliance. Ann Intensive Care. 2015;5:35.

33. Voelker MT, Jahn N, Bercker S, Becker-Rux D, Köppen S, Kaisers UX, et al. Prone positioning of patients during venovenous extracorporeal membrane oxygenation is safe and feasible. Anaesthesist. 2016;65(4):250-7.

34. Guérin C, Reignier J, Richard JC, Beuret P, Gacouin A, Boulain T, et al. Prone positioning in severe acute respiratory distress syndrome. N Engl J Med. 2013;368(23):2159-68.

35. Sud S, Friedrich JO, Adhikari NK, Taccone P, Mancebo J, Polli F, et al. Effect of prone positioning during mechanical ventilation on mortality among patients with acute respiratory distress syndrome: a systematic review and meta-analysis. CMAJ. 2014;186(10):e381-90.

36. Bloomfield R, Noble DW, Sudlow A. Prone position for acute respiratory failure in adults. Cochrane Database Syst Rev. 2015;(11):CD008095

37. Li X, Scales DC, Kavanagh BP. Unproven and expensive before proven and cheap: extracorporeal membrane oxygenation versus prone position in acute respiratory distress syndrome. Am J Respir Crit Care Med. 2018;197(8):991-3.

38. Guérin C, Beuret P, Constantin JM, Bellani G, GarciaOlivares $\mathrm{P}$, Roca $\mathrm{O}$, et al. A prospective international observational prevalence study on prone positioning of ARDS patients: the APRONET (ARDS Prone Position Network) Study. Intensive Care Med. 2018;44(1):22-37.

39. Combes A, Hajage D, Capellier G, Demoule A, Lavoué S, Guervilly C, et al. Extracorporeal membrane oxygenation for severe acute respiratory distress syndrome. N Engl J Med. 2018;378(21):1965-75.

40. Peek GJ, Mugford M, Tiruvoipati R, Wilson A, Allen E, Thalanany MM, et al. Efficacy and economic assessment of conventional ventilatory support versus extracorporeal membrane oxygenation for severe adult respiratory failure (CESAR): a multicentre randomised controlled trial. Lancet. 2009;374(9698):1351-63. 
41. Romano TG, Mendes PV, Park M, Costa ELV. Suporte respiratório extracorpóreo em pacientes adultos. J Bras Pneumol. 2017;43(1):60-70.

42. Kim WY, Kang BJ, Chung CR, Park SH, Oh JY, Park SY, et al. Prone positioning before extracorporeal membrane oxygenation for severe acute respiratory distress syndrome: A retrospective multicenter study. Med Intensiva. 2018;(18):30160-8.

43. Kallet R. ECMO vs. Prone position in ARDS: The curious rejection of evidence-based practice. Crit Care Alert. 2018;26(1):6-7.
Received in 12/04/2018

Recebido em 04/12/2018

Recibido en 04/12/2018

Approved in 04/01/2019 Aprovado em 01/04/2019 Aprobado en 01/04/2019 